\title{
THE ROLE OF MODERN GENETIC IN PREVENTION AND DIAGNOSIS OF RARE DISEASES
}

\author{
Snežana M. Stanić, Sanja Lj. Matić* \\ University of Kragujevac, Faculty of Science, Department of Biology and Ecology, \\ Radoja Domanovića 12, PO Box 60, 34000 Kragujevac, Republic of Serbia \\ *Corresponding author; E-mail: sanjamatic@kg.ac.rs
}

(Received March 31, 2017; Accepted April 25, 2017)

\begin{abstract}
In this paper, we deal with the problems encountered by those suffering from rare diseases and their families as well as the recommendations of the Council of Europe related to the activities in this field. It gives an estimate of the current situation in our country and emphasizes the need for adoption and implementation of National Plan/Strategy for rare diseases. Given the frequent dependence existing between these diseases and genetic changes, preventive and diagnostic measures have to be based on the application of modern genetics along with upholding ethical principles.
\end{abstract}

Key words: rare diseases, genetic screening, problems, recommendations

\section{INTRODUCTION}

Although many syndromes occurring in human populations were described in preceding centuries (17 and 18), only the development of medical cytogenetics and the application of various techniques for staining chromosomes have enabled their objectification since 1966 (GuĆ-ŠĆEKIĆ, 2001; MILOŠEVIĆ-ĐORĐEVIĆ, 2010). The subsequent development of molecular genetics has confirmed the assumption that proper function of genetic material makes foundations for physical and mental health in humans (STRACHMAN and READ, 2004; MiHAILOVIĆ and MiHAJLOVIĆ, 2009). DNA as a thread connecting successive cell generations and generations of descendants can be affected by various environmental agents, or spontaneously, and such altered nucleotide structure can affect the host health. Sequencing genes has proved the supposed correlation: many human diseases are caused by improper function of particular genes out of about 30,000 of those in the human genome. Thus, for example, mutations in the $C L N 3$ gene causes Batten disease; Wilson's disease is caused by mutation in the $A T P 7 B$ gene; Marfan syndrome is caused by a mutation in the FBN-1 gene; structure- and function-based mutations in the BRCA1 and BRCA2 genes are associated with familial breast cancer (BRAMBATI, 2000), etc. The list of monogenetically caused rare diseases has been expanded and has thousands of described items, whereby they are inherited as autosomal dominant, autosomal recessive, and sex-linked traits (often X-chromosome) and through mitochondrial inheritance, i.e. non-chromosomal genetic elements. Chronic lifelimiting illnesses that require specific methods of comprehensive treatment and occur in 5 out of 100,000 individuals are designated as rare (DREZGIĆ et al., 2012). Over 80\% of those result 
from a genetic defect. Regardless of the small number of sufferers in human population, problems faced by sufferers and their families are highly serious. Therefore, we will emphasize the rare diseases-related issues and suggest recommendations on how to overcome or mitigate them.

\section{RARE DISEASES ISSUES}

Beside poor prognosis, as in the case of Tay-Sachs disease children dying before their fifth birthday, rare genetically determined diseases often lead to permanent disability and lifelong medical care (STOJANOV and MARJANOvić, 2002; TuCiĆ and MATIĆ, 2002). Often, ill people and their families face with marginalisation and discrimination in society.

Adequate treatment, if there is any, is prolonged due to the inability to adequately deal with the methods of modern genetics in diagnosing. The issues in diagnosing, late registration of such diseases and lack of adequate medical care result in a number of various sociopsychological problems encountered. In addition, there are no universally accepted definitions and codification of rare diseases. Problems are often cause-consequence based and, therefore, the lack of a registry of patients suffering from such diseases hinders budget funds planning and the necessary health infrastructure (REMUZZI and GARATTINI, 2008). It is necessary for sustainable support of medical care for patients suffering from rare diseases, as well as the funding of research in this field.

So-called orphan drugs used in the treatment are expensive or unavailable, and they are of no financial interest to pharmaceutical companies (KRAJNOVIĆ et al., 2013). Also, funds for the research of the same are not sufficient.

Polls have shown that health workers do not know enough knowledge on the treatment of rare diseases, and in underdeveloped countries the system of genetic screening and counselling has not been developed. This is not in line with prevention as the utmost goal of modern health care. The role of prenatal diagnosis, pregnancy testing, and genetic screening programs is very important in dealing with rare diseases, but it requires investment in laboratory equipment and continuing education for health professionals in the field.

It is essential to establish day-care institutions, invest in social services dealing with the community integration of these patients, facilitating employment of patients with minor disability, but all mentioned above requires the development of a proper legal framework.

\section{Legislation (or Legal basis)}

The need for legal regulation and operation in accordance with the principles of bioethics was pointed out in the 90s of the last century, and in 2008 and 2009 the European Commission, in order to more fully regulate the health care of patients suffering from rare diseases, adopted two important documents providing the legal basis of future strategies for rare diseases in EU (Communication from the Commission to the European Parliament, the Council, the European Economic and Social Committee and the Committee of the Regions on Rare Diseases: Europe's Challenges (2008) and Council Recommendation of 8 June 2009 on European action in the field of rare diseases). Based on the experiences of a large number of EU member states, EUROPLAN project (EUROPLAN) started in July 2010 as a project to support the development of national plans and strategies on rare diseases in Europe (ZlataNOVIĆ, 2013). In our country, the Health Record Act (January 2016) (Zakon o zdravstvenoj dokumentaciji i evidenciji u oblasti zdravstva) stipulates the obligation of maintaining the registry of rare diseases. Article 129a of the Health Care Act (Serbian Law on Healthcare, 2011) prescribes the establishment of the Screening Board, but early newborn 
screening has not been involved, but it would enable timely detection and diagnosis of genetic defects in the pre-symptomatic stage of the disease.

\section{EURORDIS and NORBS}

The European Organisation for Rare Diseases (EURORDIS) was founded in 1997 with the main objective to raise the awareness of medical, social and bioethical issues, as well as to improve the quality of life of people living with rare diseases. This vision of EURORDIS has been accepted by many countries, and National Organization for Rare Diseases (NORBS) was founded in Serbia on 23 July 2010 as an alliance of organizations.

NORBS founders are: An association of citizens for the fight against rare diseases in children "LIFE", Association of people with cystic fibrosis in Vojvodina "SMILE", Association of patients suffering from phenylketonuria, Association of children with malignant diseases "Zvončica", Muscular Dystrophy Association of Serbia.

Its main activities are as follows:

1. Support in establishing legislative frameworks and national strategies for rare diseases;

2. The establishment of necessary health and social care infrastructure;

3. The implementation of European standards in diagnostics;

4. The implementation of European standards in the prevention and treatment of rare diseases;

5. Initiating the creation of the National Registry of Rare Diseases and the establishment of the National Rare Diseases Fund;

6. Encouraging budget support for prenatal and postnatal diagnosis of rare diseases in the country and abroad;

7. Support and assistance for people with rare diseases and their family members in exercising their rights to education and work.

At the initiative of the Institute of Public Health of Serbia and the Republic Commission for Rare Diseases, the registry comprising patients with rare diseases was started in 2014. The Health Record Act (January 2016) stipulates the obligation of maintaining the registry of rare diseases.

The registry should include the following information: principles;

1. Details of the affected person in accordance with personal data protection

2. Details of the medical institution that provide diagnosis and/or therapy;

3. Details of the disease (date of the first symptoms, date of diagnosis, disease code);

4. Data of clinical findings;

5. Data of therapy and

6. Details of the outcome of the disease (date of death if the patient died).

The International Classification of Diseases (ICD-10) has come into use in Serbia and one of the key problems is lack of proper classification and codification, so many rare diseases remain unrecognized.

Registry of rare diseases will allow:

1. Figures on prevalence of rare diseases in our country (regarding age, sex, etc.);

2. Survival analysis in patients with rare diseases;

3. Calculating disability-adjusted life years and

4. Calculating direct and indirect disease-related costs (due to patients' disability)

These data can provide:

1. Professional approach to healthcare planning;

2. Improving the organization of health care; 
3. Developing prevention programs and strategies (health education, early detection, screening, mitigating complications of rare diseases);

4. Evaluation of preventive measures implemented and

5. Assessment of rare disease burden in society

\section{Recommendations}

Modern healthcare includes preventive, diagnostic, therapeutic and rehabilitative measures that are publicly funded in countries with high levels of social welfare. In European countries the tendency is to continuously improve the quality of health care in patients with rare diseases, to explore genetic the factors of these diseases as well as to develop special classes of drugs designated as orphan drugs and to increase international cooperation in this regard. In accordance with the recommendations of the European Commission progress in Serbia has been made in several areas: improved knowledge about the epidemiology of rare diseases through education of health professionals; established national organization of patients (NORBS); developed partnerships at both national and European level (cooperation with EURORDIS); adoption of the Law on prevention and diagnostics of genetic diseases: Genetically caused anomalies and rare diseases (Official Gazette of Republic of Serbia, January 2015) resolved the question of public financial assistance for diagnostic services abroad. Research is aimed at improving, so the number of published scientific papers confirming the genetic basis of diseases is growing higher (changes affecting chromosomes or genes).

A comprehensive approach to rare diseases includes the strengthening of knowledge and skills of health professionals, thus ongoing training sessions have been conducted (MEDIĆ et al., 2016). In addition to acquiring knowledge via compulsory courses at the Faculties of Medical Sciences and Faculties of Science, public awareness campaigns have been launched encouraging motivating educational programs (designed by the members of the National Committee for Bioethics at the National Academy of Science and Art and the Centre for Bioethics in Belgrade) or media campaigns as the Rare Disease Day ("HugForRare", February 2016).

Given that about $80 \%$ of rare diseases are genetically based, it is of utmost importance to develop diagnostic and screening programs. Patients and their families should have immediate access to genetic testing and information along with the respect for the principle of equality. An important role has been given to clinical centres which provide genetic consultation. It is necessary to establish a network of healthcare institutions with qualified professionals and suitable diagnostic equipment for pregnancy testing, prenatal diagnosis, genetic consultation and to establish specialized centres for the treatment of patients.

In addition to expanding the opportunities for early diagnosis of the disease, it is necessary to establish rare disease monitoring and reporting mechanisms (by creating a raredisease registry). Although the initiative was launched back in 2014, the rare-disease registry was postponed to 2017.

It is suggested to promote the further development of orphan drugs which would undoubtedly improve the quality of life in patients. Although health insurance coverage is provided for the rare-disease drugs in Serbia, with more than 70 modern drugs in use, this number should be brought into line with a number of rare diseases registered here (GOLOČORBIN KON et al., 2013; KRAJNOVIĆ et al., 2013).

The access to health care and the promotion of social inclusion of patients and their family members, as well as genetic screening, include technical, organizational, financial, and ethical improvements. Therefore, it is necessary to continuously consider potential financial sources, other than budget financing, since in this way diagnosis and treatment can be offered to more patients. Coordination between and across health care institutions, centralized 
collecting information related to rare genetic diseases, collaboration with the institutions abroad, and raising public awareness are all factors of particular importance for patients and their families. Besides, modern genetics can also make a significant contribution.

\section{CONCLUSIONS}

The paper presents the problems and recommendations related to rare genetic diseases. We point out the conditions ensuring early diagnosis and the importance of the implementation of genetic achievements. We also refer to mechanisms for monitoring rare diseases and for a comprehensive approach to the same. Ethics-based implementation of genetic screening tests requires the improvement of organizational, technical, and financial conditions as well as the development of educational programs.

\section{Acknowledgments}

This work was financed by the Ministry of Education, Science and Technological Development, Republic of Serbia, Grants No. III 43004 and III 41010.

\section{References:}

[1] Brambati, B. (2000): Prenatal diagnosis of genetic dieases. European Journal Of Obstetrics Gynecology And Reproductive Biology 90: 165-169.

[2] Drezgić, R., Radinković, Ž., Krstić, P. (2012): Horizon of bioethics. Centar za filozofiju i društvenu teoriju, Beograd. [in Serbian]

[3] EUROPLAN: Recommendations for the development of National Plans and Strategies for Rare Diseases. Available from: www.europlanproject.eu/_newsite_986987/Resources/docs/20082011_2.EUROPLANRecommendation.pdf. Accessed 06 January 2017

[4] Goločorbin Kon, S., Vojinović, A., Lazić-Popović, M., Pavlović, N., Mikov, M. (2013): Orphan drugs. Medicinski Pregled LXVI (9-10): 373-378.

[5] GuĆ-ŠĆEKIĆ, M. (2001): Chromosomal disorders (chromosomopathies). - In: BABIĆ, M. (ed): Screening in medicine - the basis of early detection of disease. Yugoslav Foundation Against Cancer, Belgrade, 895-898 pp [in Serbian].

[6] Krajnović, D., Arsić, J., Jocić, D., Milošević-Georgiev, A., Tasić, LJ., MarinkoVIĆ, V. (2013): Evaluation of pharmacists' knowledge and attitudes regarding rare diseases and orphan drugs. Acta Medica Mediterranea 52 (2): 23-32.

[7] Law on prevention and diagnostics of genetic diseases: Genetically caused anomalies and rare diseases (Official Gazette of Republic of Serbia, January 2015). [in Serbian] Accessed 24 February 2017

[8] Medić, B., Divac, N., Stopić, B., Savić-Vujović, K., Glišić, A., Cerovac, N., StojaNOVIĆ, R., SREBro, D., Prostran, M. (2016): The attitudes of medical students towards rare diseases: A cross-sectional study. Vojnosanitetski Pregled 73 (8): 703-713. 
[9] Mihailović, LJ., MihaJlović, N. (2009): Human genetics. School for Applied Studies, Ćuprija. [in Serbian]

[10] MilošEvić-ĐorĐević, O. (2010): Principles of clinical cytogenetics. Kragujevac, Faculty of Medicine, University of Kragujevac. [in Serbian]

[11] Remuzzi, G., Garattini, S. (2008): Rare diseases: what's next? Lancet 9629 (371): 1978-1979.

[12] Serbian Law on Healthcare Official Gazette, 107/2005, 72/2009, 88/2010, 99/2010 and 57/2011 (2011). [in Serbian] Accessed 08 February 2017

[13] Stojanov, LJ., Marjanović, B. (2002): Neurometabolic hereditary diseases in children. Zavod za udžbenike i nastavna sredstva, Beograd. [in Serbian]

[14] StRAChMAN, T., READ, A.P. (2004): Human molecular genetics, 3rd edition. Garland Publishing, London.

[15] The National Organization for Rare Diseases (NORBS). Available from: http://www.norbs.rs/UI/Doc/EurordisInfo-pack-srp.pdf. Accessed 08 February 2017

[16] Tucić, N, Matić, G. (2002): About genes and humans. Centar za primenjenu psihologiju, Beograd. [in Serbian]

[17] Zakon o zdravstvenoj dokumentaciji i evidenciji u oblasti zdravstva (Sl. Glasnik RS januar/2016). [in Serbian] Accessed 11 January 2017

[18] Zlatanović, S. (2013): National plan for rare diseases - comparative legal review. Strani pravni život, 1/2013, 291-305. [in Serbian with English summary] 